The consequences of migration and colonialism II : overseas varieties

Schreier, Daniel

DOI: https://doi.org/10.1515/9783110220278.451

Posted at the Zurich Open Repository and Archive, University of Zurich

ZORA URL: https://doi.org/10.5167/uzh-27263

Book Section

Published Version

Originally published at:

Schreier, Daniel (2010). The consequences of migration and colonialism II : overseas varieties. In: Auer, Peter; Schmidt, Jürgen Erich. Language and Space : An International Handbook of Linguistic Variation. Berlin, Germany: Mouton de Gruyter, 451-467.

DOI: https://doi.org/10.1515/9783110220278.451 
Schröder, Anne

2003 Status, Functions, and Prospects of Pidgin English: An Empirical Approach to Language Dynamics in Cameroon. Tübingen: Narr.

Sebba, Mark

1997 Contact Languages: Pidgins and Creoles. London: Macmillan.

Silverstein, Michael

2003 Indexical order and the dialectics of sociolinguistic life. Language and Communication 23: $193-229$.

Thomason, Sarah G. (ed.)

1997 Contact Languages: A Wider Perspective. Amsterdam: Benjamins.

Thomason, Sarah G. and Terrence Kaufman

1988 Language Contact, Creolization, and Genetic Linguistics. Berkeley, CA: University of California Press.

Todd, Loreto

1984 Modern Englishes: Pidgins and Creoles. Oxford: Blackwell.

Whinnom, Keith

1971 Linguistic hybridization and the "special case" of pidgins and creoles. In: Dell Hymes (ed.), Pidginization and Creolization of Languages: Proceedings of a Conference Held at the University of the West Indies, Mona, Jamaica, April 1968, 91-115. Cambridge: Cambridge University Press.

Christian Mair, Freiburg (Germany)

\section{The consequences of migration and colonialism II: Overseas varieties}

1. Introduction: An "explosion of space"

2. A rough typology of overseas varieties

3. Shaping overseas varieties

4. Two illustrative scenarios

5. Conclusion

6. References

\section{Introduction: An "explosion of space"}

Societies and communities, in Europe and elsewhere, are in a constant process of shift and flux, for a variety of social, political and economic reasons: crusades and war campaigns; climatic changes and natural disasters; famines; the transformation from largely rural and self-sufficient to urbanized and monetary-based economies; etc. The last two hundred years, however, have seen population movements on an unprecedented scale, an abrupt catalyzation of sociodemographic fluctuation, both within Europe and from Europe to other continents. Many of these migratory movements take their roots in the Middle Ages and the Early Modern period: political expansionism following the discov- 
eries of seafarers and adventurers (many of them in the service of governments, such as Sir Francis Drake, Fernão de Magalhães or Amerigo Vespucci); technological innovations that made it possible to transport ever-increasing masses of personnel and cargo to new and constantly expanding numbers of destinations; the establishment of official bodies to develop international trading schemes (such as the British East India Company or the Dutch Vereenigde Oostindische Compagnie; Lawson 1993); the rivalry of the newly created nation-states for possession of overseas territories, etc.

This "explosion of space" was to have a massive impact on all the domains of language and space as discussed in the first division of articles of this handbook. First of all, it stretched and extended the space of European languages, so that French, Spanish, German, Portuguese and English (and other European languages) were exported to numerous locations around the globe, where they came into contact with - and coexisted alongside - indigenous languages. Second, the usage of the (non-local) colonizing languages would eventually cut inroads into the local sociolinguistic landscapes and massively affect the local varieties, in many cases leading to unprecedented language endangerment and death. A common scenario is for the number of speakers of English, French and Spanish to increase significantly, not because of population growth in Europe, but due to the subsequent adoption of these languages in the new territories, where they functioned as lingue franche and granted access to power and wealth. The so-called "Scramble for Africa" at the end of the nineteenth century provides a particularly pertinent case in point here (Duignan, Gann and Turner 1975). As late as in the 1880s, most of Africa was a genuine terra incognita. The Portuguese (and also, though not on the same scale, the British) had taken possession of much of the African West Coast (the Slave Coast, in the Bight of Benin; the Gold Coast, present-day Ghana; and the Ivory Coast), present-day Algeria and the Suez Canal in Egypt were under French control and Great Britain held the comparatively small Cape Colony in South Africa. It is estimated that less than ten percent of Africa was colonized when the continent became a primary target of New Imperialism (Curtin 1995). With the onset of World War I in 1914, however, the only countries outside formal European control were Ethiopia and the republic of Liberia (Bennet 1984). As a result, between 1885 and 1914, in less than thirty years, Great Britain took nearly thirty percent of Africa's population under her control, France fifteen percent, Germany nine percent, Belgium seven percent and Italy one percent. Nigeria alone was to contribute a populace of 15 million to the British Empire, which was more than the whole of French West Africa or the entire German colonial empire combined.

The "Scramble for Africa" represents a showcase scenario of the effects of political expansionism and colonialism on language and space. In terms of geographical space, an unprecedented extension into unknown territory (cf. Johnstone in this volume); in terms of cultural/social space, a reshuffling and reorganization of the local socio-ethnic landscape as well as the collapse, merging and consecutive redevelopment of social boundaries and networks in the colonial communities (cf. Mæhlum in this volume); in terms of political space, the creation of new nation states (often based on purely geographic and ethnically ignorant conceptualizations of space, along topographic rather than socio-ethnic boundaries), and a transformation of local economic systems (cf. Gal in this volume); and in terms of migration and colonization, large population movements, accompanied by the establishment of permanent settlements and enduring contacts with the colonial powers (cf. Jacquemet in this volume). Linguistically and sociolinguistically, 
the global diffusion and spatial expansion of language(s) ultimately led to the endangerment of local minority languages, often going hand in hand with the development of contact-based varieties such as pidgins and creoles (cf. Mair, this volume). On the other hand, language contact between colonizing languages (and the emergence of indigenous offspring varieties, such as Dutch-based Afrikaans in South Africa; Roberge 2002) and koinéization due to extensive dialect interaction (see below) were common as well. The "explosion of space" thus triggered a range of social, political, ethnic, economic and linguistic developments, deeply affecting all domains of language and space, and had a profound impact on Europe and the New World territories alike.

This article looks into selected aspects of language spread and diffusion and is structured as follows. It begins by providing a rough typological overview of overseas varieties, addressing the historical and societal dimension of migration and colonialism as well as the roots of the varieties under discussion more concisely. Using this as a baseline, it discusses and exemplifies some of the major linguistic and sociolinguistic outcome(s) of language transplantation, namely how extended contact triggers language change and how such contact in turn sees the "birth" of new post-colonial overseas varieties. In particular these are issues related to who is most influential in the formation of these varieties (the widely discussed concept of the "founder principle" [Mufwene 1996], as opposed to (later) dialect swamping [Lass 1990], issues related to social restructuring, settlement patterns, reforming of social networks and communities of practice, identity, etc.), whether linguistic criteria are more important than social ones or not (e.g. total percentage of input varieties), and how interaction between varieties as well as extended contact with the colonial variety affects the overall trajectory of change. A final section discusses two case studies - from Tristan da Cunha and New Zealand - and exemplifies some of the processes discussed.

\section{A rough typology of overseas varieties}

Perhaps the most important question in this context is exactly what to include under the label "overseas varieties". One should at all cost avoid the implication that these varieties are characterized by relative homogeneity (Lass 1987). In fact, the term is so general and all-inclusive that it covers just about every variety that was brought out of Europe and continued to be used elsewhere. To take the spatial extension of German, for instance, overseas varieties have developed in the Americas, Africa and in the Pacific (Timm 2001), notwithstanding the fact that Germany had a limited sphere of colonial involvement and never belonged to the colonial superpowers (Gründer 2004). To name but some offspring varieties of German around the world: Pennsylvania Dutch (a misnomer, Deutsch being misinterpreted as Dutch), certainly the most widely known form, which saw substantial input of dialects from the Palatinate; Amana German in the Amana Colonies in Iowa, founded by Inspirationalists of German origin; and several varieties in South America: Venezuelan Alemán Coloniero (with prominent input from Low Alemannic varieties), Lagunen-deutsch, which developed around Lake Llanquihue in Chile (and may have undergone extensive mixing with Spanish), and Riograndenser Hunsrückisch, formed by German Brazilians in Rio Grande do Sul, especially in the areas of Santa Catarina, Paraná and Espírito Santo (see Riehl in this handbook as well as the 
description of these varieties on Ethnologue <http://www.ethnologue.com>). In Africa, there are some 30,000 speakers of German in Namibia (former Deutsch-Südwestafrika), whereas German has not survived in Ruanda, Burundi, Tanzania or Mozambique (former Deutsch-Ostafrika, ceded to the British after World War I). A very special place in the overseas legacy of German is held by Unserdeutsch, also known as Rabaul Creole German, a German-based creole language spoken primarily in Papua New Guinea and the northeast of Australia (Holm 1989), which now is near extinction, with few bilingual speakers left. Consequently, even though the linguistic legacy of "overseas German" is limited, the varieties named display contact-linguistic complexity and have arisen due to dialect contact, language mixing and creolization.

What, then, are the major types of overseas varieties and which of them should be discussed here? Probably still one of the most important classificatory tools is the model put forward by Kachru (1985), who argued that varieties (of English, though one could easily generalize to other world languages) could be grouped in three concentric circles, depending on criteria such as historical continuity, function and use. The so-called "inner circle" represents the traditional bases of English: the United Kingdom, the United States of America, (English-speaking) Canada, Australia and New Zealand. The total number of English speakers in the inner circle amounts to approximately 380 million, the majority of whom reside in the United States. The "outer circle" (countries that were part of the British Empire) contains countries where English is not an official language but where it assumes an important institutional role and is important for historical reasons (India, Nigeria, South Africa, the Philippines, Bangladesh, Pakistan, Malaysia, Tanzania, Kenya, etc.). The total number of English speakers in the outer circle is estimated to range from 150 million to 300 million. The "expanding circle" finally, is made up of countries where English plays no historical or governmental role, but where it is nevertheless widely used as a foreign language or lingua franca (China, Russia, Japan, Korea, Egypt, Indonesia, etc.). The total number of speakers of English in this circle is most difficult to estimate, particularly since the usage of English is functionally restricted (e.g., for academic purposes or the tourism industry). Global estimates range from 300 million to more than one billion (Crystal 1997). In Kachru's view, the inner circle is "norm-providing" so that language norms are developed in these countries, mostly because English is the first (or native) language. The outer circle, by contrast, is "normreceiving" (since many speakers of English are bilingual or multilingual), whereas the expanding circle is seen as "norm-developing", due to the creative potential of foreign language speakers and language learners and the limited exposure to native-speaker norms. Kachru's model has not remained uncontroversial (Quirk 1990), but factors such as historical continuity and ancestry, mono-, bi- and multilingualism, the function and usage of a given language are certainly of utmost importance for any classification of overseas varieties.

Adopting an approach based on time depth, ancestry and affiliations with the "homeland", the presence, strength and impact of input varieties other than the colonizing language, the function and communicative role of the languages present, the sociodemographic set-up of the community, etc., then we can distinguish between directly transplanted overseas varieties, where a native-speaker tradition was maintained at all times (e.g., Falklands Islands English, Québec French, or Riograndenser Hunsrückisch), second- or foreign language varieties (English in India, Spanish in Paraguay), pidgins and creoles (e.g., English-derived Pijin on the Solomon Islands, French-derived Mauritian 
Creole, or Morisyen, on Mauritius, or Italian/Spanish-based Cocoliche in Argentina; Holm 1989), creoloids (varieties with prototypical creole features that have not developed from a pidgin, e.g., Singlish, the basilectal English used in Singapore; Platt 1975) and language varieties shaped via extensive dialect contact and koinéization (such as Australian English). It must be emphasized, however, that many, if not most, processes of new-variety formation are "messy" and that the development of overseas varieties is never clear-cut. More often than not, it is virtually impossible to delineate and isolate single processes; many of them co-occur and overlap, for instance when language and dialect contact coexist and have a joint impact on the sociolinguistic evolution of a newly forming variety.

Consequently, this article focuses on two possible outcomes, dialect contact and creoloidization, to document the complex processes of contact linguistics that underlie the formation of overseas varieties. It excludes offspring varieties of language contact, i. e., pidgins and creoles, since these are discussed by Mair (in this volume).

\section{Shaping overseas varieties}

We can single out several stages in the formation of overseas varieties. First of all, what basically happens during the formation phase of an overseas variety is that the total number of variants present in the contact scenario represents a pool out of which the first native speakers select features (Mufwene 2001). None of the input varieties "wins out" at this stage; were this the case, then all but one variety present in the contact scenario would disappear without a trace and the newly developing variety would represent the equivalent of one of its inputs. Riograndenser Hunsrückisch would merely be a transplanted (and basically unaltered) form of a Rhineland-Palatinate German dialect, Australian English exported Cockney, Québec French the equivalent of a regional variety found in France, etc. This is hardly ever the case, for reasons that are obvious. Dialects mix and interact as speakers accommodate to each other, and new dialect formation is particularly strong when children grow up in a multi-dialectal environment. The usual outcome is for the inputs to undergo a stage of mixing, so that the inception phase of a new dialect displays mechanisms of feature selection and retention. Consequently, contact between linguistic systems triggers selection processes of features from several coexisting varieties (Kerswill 1996), and this may be influenced by factors such as total number of features present, salience, stigma and prestige of individual variables, sociodemographic characteristics and social mobility, etc. Fully developed dialects, the endproduct of focusing (LePage and Tabouret-Keller 1985; see below), have thus adopted features from at least two (very often, more) donors. Put differently, a crystallizing contact-based overseas variety combines a mixture of features (phonetic, grammatical, morphological and/or lexical) that derive from some or all the dialects present in the original contact situation.

A second process is leveling: the majority of variants found in a diffuse mixture situation gradually disappear as one feature is permanently selected (Trudgill 1986; Siegel 1987; Britain 1997). Tendencies towards regularity and transparency are common in contact situations. Though the precise nature of what determines leveling is still unknown, there is consensus that status (stigma or prestige) and frequency are important 
criteria. Variants that are regionally or socially marked are usually not maintained (Mesthrie 1993) and those with the widest social and geographical distribution have the highest chances of surviving the selection process (Trudgill 1986). First, the surviving form is usually the one found in the majority of inputs (Mesthrie 1993; Siegel 1987), and this has led Trudgill (2004) to adopt an extreme (and controversial) hypothesis, namely that it should be the frequency of features alone that accounts for adoption. Social factors (prestige, status, social network structures, etc.), as a consequence, should simply be irrelevant. Such an explanatory attempt cannot account for independent developments (see below) or cases of reallocation (Trudgill 1986), when more than one original variant survives the leveling process. Reasons for reallocation are reanalysis and functional redistribution, either as social or stylistic variants, or as phonological variants in complementary environments (Britain 1997). This has been documented by Domingue (1981) in Mauritius Bhojpuri, where the total number of coexisting variants was not reduced due to the fact that former regional variants of Hindi were reinterpreted as indicators of (in)formality and style.

New Zealand English (NZE) provides a pertinent case of leveling. Schreier et al. (2003) analyzed the maintenance of voiceless labiovelar / hw-/ fricatives (minimal pairs Wales $\sim$ whales, witch $\sim$ which) in three regions of New Zealand (Otago/Southland, Canterbury and the North Island) and found considerable regional variation in early twentieth-century New Zealand English. Whereas speakers from the North Island and Canterbury were predominantly using /w/ (so that the $/ \mathrm{hw} / \sim / \mathrm{w} /$ merger was practically completed by 1950), speakers from the Southland and Otago regions had high levels of /hw-/ well into the second half of the twentieth century. The regional distribution of the variable was linked to population demographics and ancestral effects, reflecting the total input strength of $/ \mathrm{hw}-/$ retaining donor dialects. A high overall presence of $/ \mathrm{hw}-/$ variants in the inputs thus had an enhancing effect on the adoption and maintenance of the phoneme. The strong presence of / hw-/ in the Otago/Southland dialect region was explained by high input frequency and the disproportionately high input of Scottish settlers, who made a distinction between $/ \mathrm{hw}-/$ and $/ \mathrm{w}-/$. In the other regions, however, /hw-/ was not adopted, simply because the social configuration and the local contact and mixture situations were different. The inputs were mainly from the South of England, where / $\mathrm{hw}-/$ was a minority feature, and this enhanced leveling-out in the local forms of New Zealand English.

A third process involved is what some label simplification (e.g., Trudgill 1986), which however may be preferably considered as a manifestation of regularization or simply analogical language change. I personally favor the latter since the outcome of new-dialect formation is not necessarily "simpler" than any of the corresponding input forms. Rather, a given property of a variant $\mathrm{X}$, no matter if phonetic/phonological, lexical or grammatical, is subject to less variation than it was in the input varieties originally. This process manifests itself in the reduction of the quantitative range of forms. Siegel (1987: 14) points out that simplification is not well understood and argues that it should be investigated quantitatively rather than qualitatively (i.e., to adopt a variationist perspective to trace a putative decrease in variability) and to investigate it diachronically, with reference to earlier evolutionary phases of a variety (or of the input varieties). This problem is also recognized by Britain (1997: 141) who states that simplification represents "an increase in grammatical regularity and decrease in formal complexity", and Mühlhäusler (1997: 236; emphasis added), who claims that 
Simplification only refers to the form of the rules in which a language is encoded, indicating optimalization of existing rules and the development of regularities for formerly irregular aspects, for example, grammaticalization of the lexicon. Simplification is a dynamic concept. It expresses the fact that as one moves along a developmental continuum, more and more regularities appear.

A good example of phonological regularization in overseas varieties is provided by the devoicing of intervocalic alveolar plosives in Afrikaans (Booij 2002). In Dutch, voiceless alveolar plosives $(/ \mathrm{t} /)$ are voiced in intervocalic environments:

$$
/ \mathrm{t} />[\mathrm{d}] / \mathrm{V}_{-} \mathrm{V}
$$

Dutch plural formation commonly involves the affixation of an -en marker and changes the phonological environment from /-VC\#/ to /-VCV\#/. If a singular form ends in /d/, then the corresponding plural form maintains it. A voiceless /t/, however, assimilates to /d/, as in: hoed [hut] 'hat', hoeden ['hudə]. Afrikaans, in contrast, has regularized this assimilation rule so that the phonological environment has no effect on the alveolar plosive: hoed [hut] 'hat', hoeden ['hutə], stad [stat] 'city', statten ['statə]. Afrikaans is thus more regular than its ancestral variety Dutch, in that it has reduced the number of phonological rules and does not make phonological contrasts in this particular environment (Booij 2002). Similarly, a striking case of morphosyntactic regularization is found in Tristan da Cunha English (TdCE), which regularized the past tense paradigm of be (with pivot form was) to the extent that were was categorically absent from the speech of Tristanians born before World War II (Schreier 2002). One notes the interplay of simplification and regularization. A past be paradigm that has undergone regularization (we was, the fishermen was, etc.) is also in a way 'simpler'. Put differently, there is no process of simplification that does not also entail regularization, which questions whether it is necessary to keep the two terms distinct.

Finally, processes of feature selection and retention are not the only ones operating in long-term contact situations. A new dialect affiliates with its inputs by drawing its features from them, but it is erroneous to assume that it is linguistically predetermined by the distinctive properties of the varieties in contact. Contact-derived dialects may develop their own dynamics, namely when "contact between two dialects leads to the development of forms that actually originally occurred in neither dialect" (Trudgill 1986: 62). Some variants are "not actually present in any of the dialects that contribute to the mixture but ... arise out of interaction between them" (Trudgill et al. 2000), and this has been amply documented by Britain (1997) in English Fens English. According to Trudgill (1986), "interdialectalisms" represent intermediate variants of original forms (and thus originate in incomplete or faulty accommodation) or overgeneralization and hyper-adaptation (perhaps the most well-known case here is hypercorrection, which occurs when speakers misinterpret and incorrectly generalize rules by applying them to inappropriate contexts; Trudgill 1986: 66). Therefore, mixing and leveling alone cannot be offered as an explanation for all the features of a newly developing variety. Any theory that attempts to arrive at a general outline of contact-induced language change needs to leave room for independent innovation patterns.

All these processes contribute to new-dialect formation and are thus part of what LePage and Tabouret-Keller (1985) call focusing. Speakers of a fully focused variety are 
in agreement about normative structures and have a strong awareness that their dialect differs from others on linguistic grounds. Focused varieties often have a "proper" name and are accompanied by processes of standardization and codification; these reinforce attitudes towards outsiders and foster a strong sense of a local identity in the speech community's members. In so-called diffuse communities, by contrast, speakers display considerable heterogeneity (resembling the phenomenon of super-diversity), having no (or little) consensus on linguistic norms and the status of the variety. Le Page and Tabouret-Keller (1985) illustrate this with the case of multilingual Belize, where English, Creole and Spanish coexist. There is a continuum between acro- and basilectal varieties, no consensus on the usage of high-standard norms, no clear demarcation between the coexisting varieties and no agreement as to which of the varieties is used in a given context or interaction. The maintenance of multiple varieties in a contact setting is therefore a crucial factor to determine whether a variety focuses or whether it remains diffuse, and this has implications for the development of overseas varieties in general. According to Kerswill and Williams (1992: 13), the initial stages of any dialect mixture situation are characterized by extreme diffuseness. There is no agreement on shared norms in a newly founded community and language usage is characterized by the coexistence of a number of distinct variants. Variability may then be reduced when accommodation patterns between speakers in face-to-face interaction increase and social networks are implemented.

\section{Two illustrative scenarios}

The consequences of spatial extension of language are clear. First, there exist a large number of typologically and structurally distinct overseas varieties, so that the sociopolitical and linguistic landscape of any expanding language becomes richer and more diverse (often at the expense of pre-existing varieties, however). Second, the formation and evolution of overseas varieties depends on the complex interplay of language-internal and extralinguistic criteria; these influence the outcome of new varieties and must be taken into account for any attempt at reconstruction or explanatory modeling.

The remainder of the article now illustrates two of these outcomes and looks into the historical and sociolinguistic developments of two varieties in more detail: New Zealand English (NZE, which provides a scenario of dialect contact and koinéization) and Tristan da Cunha English (TdCE, which arose due to creoloidization by adopting creole features without prior pidginization or creolization).

\subsection{Dialect contact and new dialect formation: New Zealand English}

New Zealand English is the youngest of the "inner-circle" varieties of English around the world (see above), in the sense that it underwent structural nativization (Schneider 2007) most recently. European expansion into the Pacific began in the late eighteenth century, but by the 1830s, European residents in New Zealand numbered no more than around 2,000. It was only in 1840, after the Treaty of Waitangi was signed and British sovereignty was proclaimed over the country, that the European population of New 
Zealand began to grow. This occurred at a remarkable rate, however; by 1872, the European population had reached 256,000 and by 1881 almost half a million (Belich 1996: 278). In the early years of colonization, Auckland became the seat of government and it was to remain the most populous settlement. However, the period between 1840 and 1852 was also characterized by colonizing efforts of bodies in Britain that organized emigration to central and southern New Zealand. Most of the immigrants who arrived in these years came to planned settlements. Although their numbers were not great when compared with later immigration, they nevertheless laid out early patterns in the areas where they settled, particularly in Otago and Canterbury. In a sense, they represent the founders of these settlements and were to have a long-lasting impact on the colonies.

The 1871 census indicates that the vast majority of migrants in New Zealand came from the British Isles and that the English formed the largest ethnic group thereof (51 percent). The Scots, who made up ten percent of the population of the British Isles, constituted 27.3 percent of the migrants in New Zealand. They were mainly concentrated in Otago and Southland, but also settled elsewhere throughout the country. The Irish, who in 1871 made up 18.8 percent of the UK population, constituted about 22 percent of the New Zealand migrant population. The Welsh were often conflated with the English in official records but, even allowing for this, the percentage of Welsh migrants was insignificant. By 1871, the North Island provinces generally had more New Zealand born people than the South Island, and Otago and Southland had significantly more immigrants from Scotland than the other provinces. Canterbury led in the numbers from England, though the distinction between this and other provinces in the North Island was not as marked as the predominance of Scots in Otago and Southland. Here, the Scots made up between 60 to 80 percent of the total population, mostly living off agriculture (Olssen 1984: 71). The other large group consisted of miners, mostly from England and Ireland, who made up about 24 percent of the male workforce (Olssen 1984: 71). This is reflected by the settlement patterns of individual Otago towns. The population of Arrowtown, for example, a typical gold-mining town, had roughly similar proportions of settlers from England, Scotland, Ireland and Australia. Milton, on the other hand, a rural agricultural town, had a high percentage of settlers born in Scotland.

Canterbury, in contrast, was planned to be "English, Anglo-Catholic, and Conservative" (Sinclair 1991: 92). A study of the population of nineteenth-century Canterbury (Pickens 1977) shows that the "English" stereotype of the Canterbury population goes back to early settlement patterns, where fifty-five percent were of English origin, sixteen percent from Ireland, fourteen percent from Scotland and one percent from Wales. Of the English settlers, the majority came from the South of England, in particular the Southeast.

New Zealand's North Island, on the other hand, witnessed a notably different social history and higher sociodemographic fluctuation. Wellington was the earliest New Zealand Company settlement and one of the first places of European involvement. Places like Dannevirke, in contrast, were planned settlements, set up for government assisted immigrants from Scandinavia in the 1870s, and places such as Rotorua were established as late as in the 1880s. Political insecurities and struggles with the local Maori population hindered colonization of much of the North Island, but the stationing of British soldiers attracted the European population in the 1860 s. Numbers rose dramatically in the 1860 s, after war broke out between Maori and the British troops. The colonial government launched an ambitious scheme to recruit soldier settlers and to repatri- 
ate them on land confiscated from the Maori. By the mid 1860s, there were some 12,000 Imperial troops, together with 4,000 local soldiers. According to McGibbon (2000: 325), "most of those who enlisted were young single men born in Great Britain and from the lower stratum of Victorian society, laborers and semi-skilled workers attracted by the promise of a free farm". On their discharge soldiers were allotted land (the amount determined by rank) though many did not stay long enough to obtain legal ownership. For example, of the 2,056 soldier-settlers who were granted farms in the Waikato province in the 1860s, only 214 still owned farm sections in 1880 (McGibbon 2000: 327), which attests to the high degree of mobility in the North Island at the time.

Economically, the provinces of the North Island for a long time lagged behind Otago and Canterbury, where the wool and meat industry yielded high profit margins. The discovery of gold in the South Island in 1861 increased economic growth and extended the population. In the $1870 \mathrm{~s}$, a government immigration scheme was set up to boost the population in the wealthier provinces of the south, and there was a massive influx of new immigrants to Otago and Canterbury. The situation was to change from the $1880 \mathrm{~s}$ on, when the success of refrigerated shipping made the export of dairy produce possible. After 1901, more dense settlement and industrial development gave the Northern provinces an economic advantage, which led to demographic restructuring and a pre-eminent socio-political role of the North Island, which remains to the present day.

Sociolinguistically, New Zealand English is a showcase scenario to illustrate the mechanisms of new dialect formation. Though some (e.g., Hammarström 1980) have argued for monogenetic origins, taking the view that Australian English (and, by implication, New Zealand English) basically represent varieties of transplanted Cockney, most agree that New Zealand English originated in a context of dialect transplantation, contact and mixture, classifying it as a contact dialect (or koiné): "While NZE is undoubtedly southern English in origin, it shows features which are found throughout the south of England [...] NZE really is a mixed dialect, taking input from throughout Britain" (Bauer 1999: 304; emphasis added). In the words of Trudgill et al. (2000: 302), it "is the result [...] of a complex series of processes involving dialect contact between different British Isles varieties of English, followed by dialect mixture, new-dialect formation, and then by subsequent linguistic changes." The scenario that gave rise to this variety of southern hemisphere English consequently involved several transplanted inputs; their phonological and morphosyntactic properties served as a feature pool from which New Zealand English drew its features. The most eminent of these varieties was southeastern English English, or London, to be more precise. Bauer (1994: 388) states that "phonologically speaking, New Zealand English is a variant of the southeast England system", a claim supported by the qualitative and quantitative analysis reported in the ONZE ("Origins of New Zealand English") project (Gordon et al. 2004). Apparent-time data of nineteenth-century New Zealand English (the database used by the ONZE team) is indicative of early rudimentary leveling (of socially and regionally marked variants, such as the $/ \mathrm{v} \sim \mathrm{w} /$ merger) and extreme variability in the speech of the first locally born generation, whose speech is characterized by unique and often idiosyncratic combinations of features from distinct dialect regions of the British Isles. The impact of language contact was slight, manifesting itself mostly on a lexical level (Bauer 1994; Deverson 1998). Following the course of focusing and new-norm adoption, New Zealand English (like other post-colonial varieties, such as Australian English) underwent regional uniformity and leveling on a nationwide scale, as a result of which regionality does not (yet) 
correlate with language variation in present-day New Zealand English: "New Zealand, like Australia, is more remarkable for the absence of regional differences" (Gordon and Deverson 1998: 126). This has also been openly remarked on in earlier American English ("The characters chiefly noted in American speech by all who have discussed it, are, first, its general uniformity throughout the country, so that dialects, properly speaking, are confined to recent immigrants, to the native whites of a few isolated areas and to the negroes of the South"; Mencken 1921) as well as in Australian English ("Australians are for practical reasons almost completely unmarked by region within their speech community"; Bernard 1989). Indeed, this seems to be a highly diagnostic feature of the early evolutionary phase of "inner-circle" overseas varieties (see Schneider 2007 for an in-depth comparison and theoretical analysis of these varieties) and one that sets them apart from others developing in multilingual contexts.

\subsection{Dialect and creole contact: Tristan da Cunha English}

The formation of Tristan da Cunha English (TdCE) in the nineteenth century resembles that of New Zealand English to some extent, namely in that it witnessed dialect contact between varieties of British and American English. On the other hand, it shows how complex and intricately interwoven contact-induced change mechanisms are and how little it takes to alter the trajectory path of overseas varieties, particularly those developing in small, stable and locally confined founding populations.

The island of Tristan da Cunha lies in the South Atlantic Ocean, some 2,300 kilometers south of St. Helena, 2,800 kilometers west of Cape Town and about 3,400 kilometers east of Uruguay, with a current population of 285. It was discovered by the Portuguese admiral Tristão da Cunha in 1506. The English and Dutch too became aware of the islands, the Dutch being the first to effect a landing (in 1643; Beintema 2000). However, none of the colonial powers developed an interest in establishing a permanent colony on the island. Things changed when, towards the end of the eighteenth century, the American fishing and whaling industry expanded to the South Atlantic Ocean and Tristan da Cunha served as an occasional resort to the sealers and whalers (Brander 1940). The growing economic interest and strategic position along a major sea-route soon attracted discoverers, pirates and adventurers. The island was officially settled in 1816, when the British admiralty formally annexed Ascension Island and Tristan da Cunha, apparently with the intention of blocking a possible escape route for Napoleon Bonaparte, who at the time was exiled on the island of St. Helena (Schreier and Lavarello-Schreier 2003). A military garrison was dispatched to the island, withdrawing after one year only. Some army personnel stayed behind with the intention of settling permanently: two stonemasons from Plymouth (Samuel Burnell and John Nankivel) a non-commissioned officer from Kelso, Scotland, named William Glass, his wife, "the daughter of a Boer Dutchman" (Evans 1994: 245), and their two children.

The population increased when shipwrecked sailors and castaways arrived; some of them stayed behind and added to the permanent population. In 1824, apart from the Glass family, the settlers included Richard "Old Dick" Riley (from Wapping, East London), Thomas Swain (born in Hastings, Sussex) and Alexander Cotton (from Hull/Yorkshire), who had arrived in the early 1820s (Earle [1832] 1966). The late 1820s and 1830s saw the arrival of a group of women from St. Helena and three settlers from Denmark 
and the Netherlands. The population grew rapidly and by 1832 there was a total of 34 people on the island, 22 of whom were young children. The 1830s and 1840s saw a renaissance of the whaling industry and numerous ships called at Tristan da Cunha to barter for fresh water and supplies; this led to the arrival of American whalers, some of whom settled permanently.

The second half of the nineteenth century was a period of growing isolation, for a number of political and economic reasons. The whale trade declined quickly, the increasing use of steam ships made bartering unnecessary, and the opening of the Suez Canal in 1869 drastically reduced the number of ships in the South Atlantic Ocean. This affected the influx of settlers and a weaver from Yorkshire (Crawford 1945) and two Italian sailors were the only new arrivals in the second half of the century (Crabb 1980). The state of self-sufficiency and isolation lasted well into the twentieth century. When visiting the island in 1937, the Norwegian sociologist Peter Munch found that the Tristanians had not partaken in the massive changes that had occurred in the western world (Munch 1945) and noted that they basically lived in non-industrialized conditions. This situation came to an abrupt end in April 1942, when the British admiralty ordered the installation of a naval station on Tristan da Cunha. The arrival of the navy corps entailed farreaching economic changes and a South African company obtained exclusive rights to establish a permanent fishing industry on the island, employing practically the entire local workforce. The traditional subsistence economy was replaced by a paid labor force economy, and the traditional way of life was modified as a result of the creation of permanent jobs with regular working hours. Tristan da Cunha was an economic boomtown in the 1950s: the living conditions and housing standards improved and the changes brought about by the development scheme led to a complete transformation of the traditional Tristanian way of life within one generation. These social changes had linguistic consequences as local dialect features eroded via accommodation to and adoption of outside norms (Schreier 2002, 2003).

In October 1961, unforeseen volcanic activities forced a wholesale evacuation of the entire population. The Tristanians had to leave the island and were transported to England; virtually all of them returned from their exile to the South Atlantic in 1963. The dramatic evacuation and the two "volcano years" in England affected the islanders more than any other single event in the history of the community. The community underwent quick modernization and adaptation to western culture. A new fishing company provided all the households with electricity; this improved the living conditions considerably and the 1970s and 1980s were a period of economic prosperity again, which led to an increase in mobility (mostly for secondary education and further job training) and a quick opening-up of the community.

How did the settlement history and population dynamics shape the development of a local indigenous variety, and exactly what is the sociolinguistic status of Tristan da Cunha English as an overseas variety of English? As Zettersten (1969) points out, it is crucial that there was no indigenous population when the island was colonized. Consequently, the community's founders found themselves in tabula rasa conditions and did not come into contact with pre-existing language varieties (a major difference to practically all locales in the Caribbean and Africa). The English input varieties to Tristan da Cunha English were dialects from the British Isles (the founders came from the Scottish Lowlands, East Yorkshire, East London and Hastings), the United States (from the New England area; Captain Andrew Hagan, the most influential American resident, was a native of New London, Massachusetts) and from St. Helena. The first languages of the 
non-British settlers were Afrikaans, Danish, Dutch and Italian. Several kinds of linguistic contact thus operated during the genesis and formation periods of Tristan da Cunha English, as the following varieties of English were transplanted to the island: British and American English (which led to koinéization), second language (L2) forms of English (as spoken by the settlers from Denmark, the Netherlands and Italy) and St. Helenian English (StHE), which emerged in context of intense language contact involving English, various African and Asian languages and Malagasy (Schreier 2008). Some (e.g., Hancock 1991) have suggested that StHE may have undergone creolization, so that it is structurally similar to English-based creoles in the North Atlantic. This seems to be a strong claim, but the parallels (particularly in morphosyntax) are obvious; they are of high diagnostic value since there were practically no sociodemographic connections between St. Helena and the Caribbean (see Schreier 2008), excluding the possibility of direct transmission. As for, this variety primarily derives from varieties of British/late eighteenth-century American English and StHE, which served as the most important donors to this variety, and it can be excluded that Tristan da Cunha English emerged in a context of direct language contact. There is first-hand evidence that all the Tristan settlers had at least some knowledge of English (for instance, a visiting captain described the English of the Dutch settler as "excellent", quoted in Brander [1940: 157]; cf. also Earle 1832; Taylor 1856), which excludes pidginization and creolization effects on Tristan da Cunha. On the other hand, these L2 forms had an impact on Tristan da Cunha English and several non-native features were adopted when the local variety nativized (th-sibilization, i. e., dental fricatives realized as /s/, as in think, throw, etc.).

The existence of Creole-type features in Tristan da Cunha English (such as extremely high rates of consonant cluster reduction and absence of -ed past tense marking [Schreier 2005: 152]; /v/ realized as [b]; lack of word-order inversion in questions; copula absence; etc.) can only mean that a creolized form of English was transplanted via (at least some of) the women who cross-migrated in the 1820s from St. Helena. These women had some proficiency in English (Taylor [1856] reports that no other languages were spoken on Tristan in 1851) and they most likely spoke a (perhaps mesolectal) English-based Creole, so that these features were adopted by the first generations of native Tristanians. Zettersten (1969: 134-5) reaches a similar conclusion when stating that "the speechhabits of the settlers from St. Helena may have contributed towards simplifying the inflectional structures of the Tristan dialect." Similarly, Cassidy (1974: 176), in his review of Zettersten (1969), states that Tristan da Cunha English "did not develop its pidgincreole as Pitcairn did, but appears to have imported many common creole features". Processes of admixture and creole contact have been documented in other varieties of English around the world, and simplification as a result of extensive contact with a regularized or simplified variety is found in Afrikaans (Roberge 2002) or Singapore English (Platt 1975). Accordingly, Tristan da Cunha English is a prominent example of what is most aptly called creoloidization. In Trudgill's (2000: 182) words, a creoloid

demonstrates a certain amount of simplification and admixture, relative to some source language, [...] which has never been a pidgin or a creole in the sense that it has always had speakers who spoke a variety which was not subject to reduction.

Thus, Tristan da Cunha English emerged in a context of dialect contact, yet witnessed admixture with an English-derived creole variety and had at the same time some input of ESL and learner varieties of English, which may well represent one of the most complex development histories of all the overseas varieties we know of. 


\section{Conclusion}

What general conclusions can we draw from the massive expansion of language(s) on a global scale and how does the emergence and disappearance of overseas varieties challenge us to rethink the relationship between language and space? First of all, the unprecedented amount of language diffusion and spread out of Europe and into the "New World" led to the emergence of countless "new" varieties, shaped in diverse contact settings around the globe. These developments affected all the dimensions of space (geographic, cultural/social, political) and enriched the geo- and sociolinguistic landscape of European languages, as these came into contact with each other (most notably when two colonizing powers vied for the same territory, as in Vanuatu or South Africa) and of course with countless pre-existing local varieties. Regular interaction and subsequent accommodation fostered a variety of sociolinguistic outcomes (trade jargons, pidgins and creoles with European lexifiers, contact dialects, etc.). At the same time, the shaping of overseas varieties had a massive impact on the usage of local languages and is/was instrumental for the alarming rate of language endangerment and death (see the highly emotional debate about European "killer languages"; Skutnabb-Kangas 2000). By the same token, the last decades in turn have witnessed a decrease of many overseas varieties, some of which have already disappeared, for reasons such as renewed social mobility, in- and out-migration, or increasing stigmatization and nationalism (to mention many of the overseas varieties of German in the USA; Bonin/Ogasawara English in Japan, Long 2007; Riograndenser Hunsrückisch in Brazil; Unserdeutsch in Papua New Guinea; Cocoliche in Argentina; and many more).

From a theoretical perspective, the search for a general framework to account for these varieties is now at the forefront of linguistics, yet the immensely complex processes that underlie colonization and its sociolinguistic conglomerates mar such efforts considerably. The problem is that so many contact settings are far from straightforward, that practically all colonies witness a steady coming and going, a frequent reshuffling of their sociodemographic set-ups, and that there is an ever-changing coexistence of language varieties (local and indigenous languages, social and regional varieties of the same language, etc.). As a result, all contact scenarios are "messy" and simply do not lend themselves to the neat separation and classification researchers hope to come up with. The scope and importance of overseas varieties for research on language and society is immense, however, affecting disciplines as diverse as contact linguistics, historical linguistics, language variation and change, language endangerment and death, typology and universals and many more. This is the legacy of the spatial expansion of language, and the emergence, evolution and disappearance of overseas varieties now has a central role in linguistic theory.

\section{References}

Bauer, Laurie

1994 Introducing the Wellington corpus of written New Zealand English. Te Reo 37: 21-28. Bauer, Laurie

1999 On the origins of the New Zealand accent. English World-Wide 20: 287-307. 
Beintema, Albert

2000 Early Shipping in Tristan da Cunha Waters. Available at $<$ http://www.beintema.com/ ships.htm >, last accessed: May 6, 2009.

Belich, James

1996 Making Peoples: A History of the New Zealanders from Polynesian Settlement to the End of the Nineteenth Century. Auckland: Penguin.

Bennet, Norman R.

1984 Africa and Europe: From Roman Times to National Independence. 2nd ed. New York: Holmes \& Meier.

Bernard, John R.

1989 Regional variation in Australian English: A survey. In: Peter Collins and David Blair (eds.), Australian English: The Language of a New Society, 255-259. St Lucia: University of Queensland Press.

Booij, Geert

2002 The balance between storage and computation in the language faculty. Science Prestige Lecture given at the University of Canterbury, Christchurch, 30 July.

Brander, Jan

1940 Tristan da Cunha 1506-1902. London: Allen and Unwin.

Britain, David

1997 Dialect contact and phonological reallocation: "Canadian raising" in the English Fens. Language in Society 26: 15-46.

Cassidy, Fred

1974 Review of Arne Zettersten's “The English of Tristan da Cunha”. Language 50: 175-177.

Crabb, George

1980 The history and postal history of Tristan da Cunha. Self-published manuscript.

Crawford, Allen

1945 I Went to Tristan. London: Allen and Unwin.

Crystal, David

1997 English as a Global Language. Cambridge: Cambridge University Press.

Curtin, Philip (ed.)

1995 African History: From Earliest Times to Independence. 2nd ed. Boston: Addison Wesley.

Deverson, Tony (ed.)

1998 The New Zealand Oxford Paperback Dictionary. Auckland: Oxford University Press.

Domingue, Nicole

1981 Internal change in a transplanted language. Studies in the Linguistic Sciences 4: 151-159.

Duignan, Peter, Lewis H. Gann and Victor W. Turner (eds.)

1975 Colonialism in Africa, 1870-1960. Cambridge: Cambridge University Press.

Earle, Augustus

[1832] 1966 Narrative of a Residence on the Island of Tristan D'Acunha in the South Atlantic Ocean. Oxford: Clarendon Press.

Evans, Dorothy

1994 Schooling in the South Atlantic Islands 1661-1992. Oswestry: Anthony Nelson.

Gordon, Elizabeth and Tony Deverson

1998 New Zealand English and English in New Zealand. Auckland: New House Publishers.

Gordon, Elizabeth, Lyle Campbell, Jennifer Hay, Margaret Maclagan, Andrea Sudbury and Peter

Trudgill

2004 New Zealand English: Its Origins and Evolution. Cambridge: Cambridge University Press.

Gründer, Horst

2004 Geschichte der deutschen Kolonien. 5th ed. Paderborn: Schöningh.

Hammarström, Göran

1980 Australian English. Its Origins and Status. Hamburg: Helmut Buske. 
Hancock, Ian

1991 St. Helena English. In: Francis Byrne and Thom Huebner (eds.), Development and Structures of Creole Languages. Amsterdam/Philadelphia: Benjamins.

Holm, John

1989 Pidgins and Creoles. 2 vols. Cambridge: Cambridge University Press.

Kachru, Braj B.

1985 Standards, codification, and sociolinguistic realism: The English language in the outer circle. In: Randolph Quirk and Henry G. Widdowson (eds.), English in the World, 1130. Cambridge: Cambridge University Press.

Kerswill, Paul

1996 Children, adolescents and language change. Language Variation and Change 8: 177-202.

Kerswill, Paul and Anne Williams

2000 Creating a new town koiné: Children and language change in Milton Keynes. Language in Society 29: 65-115.

Lass, Roger

1987 The Shape of English. Structure and History. London: Dent.

Lass, Roger

1990 Where do extraterritorial Englishes come from? Dialect input and recodification in transported Englishes. In: Sylvia Adamson, Vivien Law, Nigel Vincent and Susan Wright (eds.), Papers from the 5th International Conference on English Historical Linguistics, 245-280. (Current Issues in Linguistic Theory 65.) Amsterdam/Philadelphia: Benjamins.

Lawson, Philip

1993 The East India Company: A History. (Studies in Modern History Series.) London: Longman.

LePage, Robert and Renée Tabouret-Keller

1985 Acts of Identity. Cambridge: Cambridge University Press.

Long, Daniel

2007 English on the Bonin (Ogasawara) Islands. (Publication of the American Dialect Society 91.) Durham NC: Duke University Press.

McGibbon, Ian (ed.)

2000 The Oxford Companion to New Zealand Military History. Auckland: Oxford University Press.

Mencken, Henry Louis

1921 The American Language. New York: Knopf.

Mesthrie, Rajend

1993 Koineization in the Bhojpuri-Hindi diaspora - with special reference to South Africa. International Journal of the Sociology of Language 99: 25-44.

Mufwene, Salikoko

1996 The founder principle in creole genesis. Diachronica 13: 83-134.

Mufwene, Salikoko

2001 The Ecology of Language Evolution. Cambridge: Cambridge University Press.

Mühlhäusler, Peter

1997 Pidgin and Creole Linguistics. 2nd ed. (Westminster Creolistics Series 2.) London: Battlebridge.

Munch, Peter A.

1945 Sociology of Tristan da Cunha. Oslo: Det Norske Videnskaps-Akademi.

Olssen, Erik

1984 A History of Otago. Dunedin: McIndoe.

Osterhammel, Jürgen

1995 Kolonialismus: Geschichte, Formen, Folgen. Munich: Beck.

Pickens, Keith A.

1977 The origins of the population of nineteenth century Canterbury. New Zealand Geographer 33: $60-75$. 
Platt, T.

1975 The Singapore English speech continuum and its basilect "Singlish" as a "creoloid". Anthropological Linguistics 17(7): 363-374.

Quirk, Randolph

1990 Language varieties and standard language. English Today 21: 3-10.

Roberge, Paul T.

2002 Afrikaans - considering origins. In: Rajend Mesthrie (ed.), Language in South Africa, 79-103. Cambridge: Cambridge University Press.

Schneider, Edgar W.

2007 Postcolonial English. Varieties around the World. Cambridge: Cambridge University Press.

Schreier, Daniel

2002 Past be in Tristan da Cunha: The rise and fall of categoricality in language change. American Speech 77: 70-99.

Schreier, Daniel

2003 Isolation and Language Change: Sociohistorical and Contemporary Evidence from Tristan da Cunha English. Houndmills, Basingstoke/New York: Palgrave Macmillan.

Schreier, Daniel

2005 Consonant Change in English Worldwide: Synchrony Meets Diachrony (Palgrave Studies in Language History and Language Change 3.) Houndmills, Basingstoke/New York: Palgrave Macmillan.

Schreier, Daniel

2008 St Helenian English: Origins, Evolution and Variation (Varieties of English around the World Series.) Amsterdam/Philadelphia: Benjamins.

Schreier, Daniel and Karen Lavarello-Schreier

2003 Tristan da Cunha. History People Language. London: Battlebridge.

Schreier, Daniel, Elizabeth Gordon, Jennifer Hay and Margaret Maclagan

2003 The regional and sociolinguistic dimension of $/ \mathrm{hw}-/$ maintenance and loss in early 20th century New Zealand English. English World-Wide 24: 245-269.

Siegel, Jeff

1987 Language Contact in a Plantation Environment. Cambridge: Cambridge University Press.

Sinclair, Keith

1991 A History of New Zealand. 4th ed. Auckland: Penguin.

Skutnabb-Kangas, Tove

2000 Linguistic Genocide in Education - or Worldwide Diversity and Human Rights? Mahwah, $\mathrm{NJ} /$ London: Lawrence Erlbaum Associates.

Taylor, William F.

1856 Some Account of the Settlement of Tristan d'Acunha in the South Atlantic Ocean. London: Cassell.

Timm, Uwe

2001 Deutsche Kolonien. Cologne: Parkland.

Trudgill, Peter

1986 Dialects in Contact. Oxford: Blackwell.

Trudgill, Peter

2000 Sociolinguistics: An Introduction to Language and Society. 4th ed. London: Penguin.

Trudgill, Peter

2004 New-Dialect Formation: The Inevitability of Colonial Englishes. Edinburgh: Edinburgh University Press.

Trudgill, Peter, Elizabeth Gordon, Gillian Lewis and Margaret Maclagan

2000 Determinism in new-dialect formation and the genesis of New Zealand English. Journal of Linguistics 36: 299-318.

Zettersten, Arne

1969 The English of Tristan da Cunha. (Lund Studies in English 37.) Lund: Gleerup.

Daniel Schreier, Zürich (Switzerland) 